\title{
Fighting African capital flight: trajectories, dynamics, and tendencies
}

\author{
Simplice A. Asongu ${ }^{1 *}$ (D) Joseph I. Uduji ${ }^{2}$ and Elda N. Okolo-Obasi ${ }^{3}$
}

\author{
* Correspondence: asongusimplice@ \\ yahoo.com; asongus@afridev.org \\ ${ }^{1}$ Research Department, African \\ Governance and Development \\ Institute, P. O. Box 8413, Yaoundé, \\ Cameroon \\ Full list of author information is \\ available at the end of the article
}

\begin{abstract}
This study provides a harmonization framework for common capital flight policies in Africa. It builds on evidence of persistent extreme poverty in the continent to assess how common measures can be adopted by sampled countries on one cause of extreme poverty: capital flight. The dataset is sub-divided into fundamental characteristics of African capital flight based on income levels, legal foundations, natural resources, political stability, regional proximity, and religious domination. The main finding shows that from a projection date of 2010, a feasible timeframe for harmonizing policies is between 2016 and 2023. This timeframe coincides with the beginning of the post-2015 agenda on sustainable development goals.
\end{abstract}

Keywords: Econometric modeling, Capital flight, Poverty, Africa

JEL classification: C50, E62, F34, O19, O55

\section{Introduction}

There are at least four reasons for reviewing Asongu (2014a) on "Fighting African Capital Flight: Empirics on Benchmarking Policy Harmonization": (i) recent extreme poverty trends in Sub-Saharan Africa (SSA); (ii) a critique of Piketty's Capital in the twenty-first Century that builds on capital flight to elucidate the sub-region's extreme poverty; (iii) a recent methodological innovation for common policy initiatives based on negative macroeconomic and institutional signals (reverse Solow-Swan); and (iv) the imperative to account for more fundamental characteristics of the sub-region's development in order to inform policy formulation and enable a robust response.

First, an April 2015 World Bank report on the attainment of the Millennium Development Goal (MDG) extreme poverty target has revealed that extreme poverty has been decreasing in all regions of the world, with the exception of Africa, where $45 \%$ of countries in SSA are substantially off track in terms of achieving the MDG extreme poverty target (World Bank, 2015). As documented in recent literature (Efobi et al., 2018; Asongu and Kodila-Tedika, 2017; Tchamyou, 2019a, 2019b; Tchamyou et al., 2019; Asongu \& le Roux, 2017, 2019), whereas extreme poverty has been declining in all regions of the world, it has been increasing in SSA. This is despite over two decades of growth resurgence that began in the mid-1990s.

Second, responding to the increasing poverty levels in SSA, Asongu and Nwachukwu (2016a) present a critique of Piketty (2014) Capital in the twenty-first Century. Building on: (i) responses from Kenneth Rogoff and Joseph Stiglitz; (ii) post-Washington

(c) The Author(s). 2020 Open Access This article is distributed under the terms of the Creative Commons Attribution 4.0 International License (http://creativecommons.org/licenses/by/4.0/), which permits unrestricted use, distribution, and reproduction in any medium, provided you give appropriate credit to the original author(s) and the source, provide a link to the Creative Commons license, and indicate if changes were made. 
Consensus paradigms; and (iii) underpinnings from Boyce-Fofack-Ndikumana and Solow-Swan, Asongu and Nwachukwu (2016a) conclude that extreme poverty in SSA would increase as long as the return on political economy (or illicit capital flight) is higher than the growth rate in the sub-region.

Third, a recent stream of literature builds on theoretical underpinnings of neoclassical growth models to propose the need for common policies based on negative macroeconomic and institutional signals. In essence, whereas the theoretical underpinnings of income convergence have exclusively been limited to catch-up in positive signals, a new stream of literature is evolving on catch-up in negative signals. According to this stream, it is more relevant to initiate common policies based on negative signals because these are policy syndromes by conception and definition. The three most prominent studies in this stream of literature are: (i) Asongu (2013) on harmonizing policies against software piracy; (ii) Asongu and Nwachukwu (2016b), who predicted the 2011 Spring using negative signals in institutional and macroeconomic variables; and (iii) Asongu (2014a) on benchmarking policy harmonization against capital flight in SSA.

Fourth, Asongu (2014a) uses two fundamental characteristics to project horizons for common policies against capital flight in SSA. We extend the underlying study by accounting for income levels, legal foundations, regional proximity, and religious domination. In essence, accounting for more fundamental characteristics of the sub-region's development is essential in order to inform policy formulation and enable a robust response. Accordingly, upholding blanket policies in the battle against capital fight may not be effective unless they are contingent on fundamental characteristics and prevailing trajectories of capital flight in SSA. Hence, policy makers are most likely to ask the following three questions before considering the harmonization of policies on capital flight: (i) Is capital flight converging within SSA? (ii) If so, what is the degree and timeframe of the convergence process? (iii) For which relevant fundamental characteristics of capital flight do answers to the first and second questions apply? While an answer to the first question will guide the feasibility of harmonizing blanket policies, the answer to the second will determine an optimal timeframe for the blanket policies. However, ultimately, the answer to the third (given that the first and second questions are already answered), will determine the feasibility of, timeframe for, and exclusiveness (or nonarbitrariness) of the common policies. This third question is the most relevant because it underlines the need for common policies to be contingent on the prevailing speeds of, and time required for, full (100\%) convergence within each identified fundamental characteristic of capital flight.

The focus of the research also departs from contemporary literature on capital flight, which has been oriented towards, inter alia: the connection between fiscal policy and capital flight (Muchai \& Muchai, 2016); lessons on causes and effects of capital flight from Africa (Ndikumana, 2016); the connection between capital flight and public social expenses in Madagascar (Ramiandrisoa and Rakotomanana, 2016) and CongoBrazzaville (Moulemvo, 2016); insights into relationships between mis-invoicing in trade and the flight of capital from Zimbabwe by Kwaramba et al. (2016); the nexus between natural resources and capital flight in Cameroon (Mpenya et al., 2016); how capital flight is related to tax income in Burkina Faso (Ndiaye \& Siri, 2016); linkages between terrorism, capital flight, and military expenditure (Efobi \& Asongu, 2016; 
Asongu \& Amankwah-Amoah, 2018); the effects of the institutional environment on the nexus between capital flows and capital flight by Gankou and Bendoma (2016); the bundling and unbundling of institutions in the fight against capital flight (Asongu \& Nwachukwu, 2017); and how terrorism sustains the addiction to capital flight (Asongu et al., 2019).

The rest of the paper is organized in the following manner. Section 2 presents the data and methodology, Section 3 the empirical analysis and discussion of results, and Section 4 concludes.

\section{Data and methodology \\ Data}

The research focuses on 37 countries in Africa, using data for the period 1980 to 2010 from a plethora of sources: Boyce and Ndikumana (2012a); the African Development Indicators (ADI); and the Financial Development and Structure Database (FDSD) of the World Bank. The geographical and temporal scope of the research is contingent on the availability of data at the time of the study. The capital flight data come from Boyce and Ndikumana (2012a), and at the time of the study only 37 countries were available for the corresponding periodicity. Insights into the sampled countries and related categories are disclosed in Appendix 4. In what follows, some essential points surrounding the selection of data are clarified, notably: (i) the determination of fundamental features, (ii) how the capital flight measure is comparable and compatible and (iii) choice of control variables.

\section{Determination of fundamental characteristics}

Building on the attendant scholarship, it is not feasible to establish convergence when sampled countries exhibit significant heterogeneity (Asongu, 2013). In view of improving the homogenous characterization of the dataset, it is classified based on certain fundamental characteristics pertaining to capital flight. In the choice of these fundamental features, governance (inter alia, regulation quality, corruption-control, and transparency) and macroeconomic features have the shortcoming of being dynamic over time. Therefore, an adopted threshold may be inconsistent within the sampled periodicity, especially given the length of the sample (i.e., a 30-year span).

In light of the above, the research follows Weeks (2012) in the selection of fundamental features, using petroleum-exporting and conflict-affected countries, inter alia. In addition to these features, this study uses the following categorizations: religious domination, legal foundations, and income levels. Whereas the categorization approach employed by Weeks (2012) is exclusive, there is a consensus in the literature that "conflicts" and political strife, as well as a reliance on the petroleum industry, influence the macroeconomic performance of African countries (Boyce \& Ndikumana, 2012a, 2012b). Moreover, there are some apparent issues in the assignment of countries to the selected categories on an exclusive and non-arbitrary basis. In order to avoid repetition, more information on the adopted categories can be found in Asongu (2014a), which builds on a body of literature for the categorization of countries, notably: Weeks (2012), Boyce and Ndikumana (2003, 2012a), La Porta et al. (1998) and Asongu (2014b). 


\section{Comparability and compatibility of the capital flight measurement}

There are two principal shortcomings associated with the capital flight measurement: (i) it is not compatible with underpinnings of the convergence theory, and (ii) it is not comparable with other variables in the study. The measurement of capital flight from Boyce and Ndikumana (2012a) is expressed in constant 2010 USD (in millions). Two conclusions can be drawn from the nature of the indicator: on the one hand, the indicator cannot be compared with attendant control variables that are largely expressed in current USD-GDP ratio; on the other, the indicator is incompatible with the GDP-centric endogenous indicators from the attendant convergence scholarship. In order to tackle the discussed concerns, this study is consistent with Asongu (2014a) by first converting current GDP to constant 2010 terms. The value obtained is then divided by 1,000,000, from which values in terms of "GDP constant of 2010 USD (in millions)" are obtained. The last step of the process consists of dividing the capital flight values from the second step by "GDP constant of 2010 USD (in millions)". As apparent in Appendix 1, the transformation produces a measurement of capital flight that is compatible with the theoretical underpinnings pertaining to the convergence literature, and with the other variables.

\section{Control variables}

In accordance with Asongu (2014a), 14 variables are adopted for the conditioning information set. These elements in the conditioning information set are used in two distinct specifications that account for trade and financial globalization (i.e., trade openness, private capital flows, and foreign direct investment), expenditure of the government (i.e., public investment and government spending), economic prosperity (i.e., GDP per capita growth and GDP growth), institutional quality (i.e., rule of law and regulation quality), the stability of prices (i.e., inflation), financial development (i.e., liquid liabilities and money supply), and development assistance (entailing total foreign aid and foreign aid from the $\mathrm{DAC}^{1}$ countries). It is worthwhile to clarify that the choice of the variables is consistent with the theoretical insights into conditional convergence, which maintain that if there are disparities between countries in institutional and macroeconomic features that are exogenous to capital flight, conditional convergence is likely to be apparent. According to Asongu (2015), globalization drives capital flight. Boyce and Ndikumana (2012b) maintain that one of the most critical mechanisms by which government funds are stolen is through public spending. Weeks (2012) posits that capital flight is associated with high dependence on foreign aid and low quality of institutions. It is documented in the literature that investors prefer investing in economies that are less characterized by features of ambiguity (Kelsey \& le Roux, 2017, 2018) such as very high inflation. In line with Boyce and Ndikumana (2003), high levels of economic growth that are not driven by petroleum exports are linked with lower levels of capital flight, in the light of higher anticipated returns from investment. Insights into the summary statistics, correlation matrix, and definitions of variables are presented in Appendix 1, Appendix 2, and Appendix 3, respectively.

${ }^{1}$ Development Assistance Committee 


\section{Methodology}

This research uses the beta $(\beta)$ convergence technique that is in line with the methodological motivations of the paper. This is consistent with literature that emphasizes the need for the adopted estimation technique to be compatible with data behavior and the study's objective (Chao et al., 2019; Zhang et al., 2019; Li et al., 2014, 2016; Kou et al., $2012,2014,2016,2019,2019)$. This procedure of estimation is typically in line with the income catch-up scholarship that builds on models of neoclassical growth, notably: Baumol (1986); Barro and Sala-i-Martin (1992, 1995), and Mankiw et al. (1992). The attendant theoretical insights have been extended to other areas of development studies, including financial markets and financial intermediary developments (Narayan et al., 2011; Tchamyou \& Asongu, 2017; Tchamyou et al., 2018; Efobi et al., 2019).

Following the attendant convergence studies (Fung, 2009; Asongu, 2013), Eq. (1) and Eq. (2) below are the main specifications used to assess conditional convergence if $W_{i, t}$ is taken as strictly exogenous.

$$
\begin{aligned}
& \ln \left(Y_{i, t}\right)-\ln \left(Y_{i, t-\tau}\right)=\beta \ln \left(Y_{i, t-\tau}\right)+\delta W_{i, t-\tau}+\eta_{i}+\xi_{t}+\varepsilon_{i, t} \\
& \ln \left(Y_{i, t}\right)=\sigma \ln \left(Y_{i, t-\tau}\right)+\delta W_{i, t-\tau}+\eta_{i}+\xi_{t}+\varepsilon_{i, t}
\end{aligned}
$$

Where $Y_{i, t}$ represents the measure of capital flight of country $i$ in period $t . \sigma=1+\beta$. $W_{i, t}$ denotes a vector of capital flight determinants, $\eta_{i}$ reflects a country-specific effect, $\xi_{t}$ is a time-specific constant, and $\varepsilon_{i, t}$ an error term. In light of the neoclassical growth underpinnings discussed in the preceding paragraph, a statistically significant negative coefficient on $\beta$ in Eq. (1) implies that, countries that are comparatively close to their steady states in terms of changes in capital flight will be characterized by a slowdown in capital flight growth (Narayan et al., 2011). Within the same framework, as documented in Fung (2003) and in contemporary literature on convergence, if $0<|\sigma|<1$ in Eq. (2), it follows that $Y_{i, t}$ is stable dynamically with a capital flight growth rate trend that is similar to that of $W_{t}$, and with a corresponding height relative to the level of $W_{t}$. These indicators are encapsulated in $W_{i, t-\tau}$, and the individual effects $\eta_{i}$ are measurements of the long-term capital flight convergence path. It follows that the countryspecific effect $\eta_{i}$ articulates other drivers of the steady state of the country that are not observed in $W_{i, t-\tau}$.

In order to eliminate fixed effects that can cause endogeneity owing to the correlation between the lagged outcome variable and fixed effects, the difference of Eq. (2) is taken to produce Eq. (3).

$$
\begin{aligned}
\ln \left(Y_{i, t}\right)-\ln \left(Y_{i, t-\tau}\right)= & \sigma \ln \left(Y_{i, t-\tau}-Y_{i, t-2 \tau}\right)+\delta\left(W_{i, t-\tau}-W_{i, t-2 \tau}\right)+\left(\xi_{i, t}-\xi_{i, t-\tau}\right) \\
& +\left(\varepsilon_{i, t}-\varepsilon_{i, t-\tau}\right)
\end{aligned}
$$

Eq. (2) and Eq. (3) are then combined within a framework of a generalized method of moments (GMM), that ensures parallel conditions between the dependent variables and error terms by using lagged differences of the regressors as instruments in Eq. (2) and lagged levels of the regressors as instruments in Eq. (3). The choice of the system estimator of the GMM technique (Arellano \& Bond, 1991) over the difference estimator of the same technique (Arellano \& Bover, 1995; Blundell \& Bond, 1998) is 
motivated by the need to obtain more efficient estimates, as Bond et al. (2001) document. The specification is two-step in order to account for heteroscedasticity.

As Islam maintains ((1995), 14), it is not appropriate to assess convergence using yearly time spans because these are too short, and consequently short-term disturbances may persist. Therefore, given a dataset spanning 31 years, the research follows Asongu (2013) in employing two-year data averages in terms of non-overlapping intervals (NOI). In addition to the justification provided above, four more additional motivations are worth clarifying. (i) While NOI that are characterized by higher numerical values absorb more short-term disturbances, there is also an associated shortcoming of having estimated models that are weakened in the light of the information criteria used to assess and validate them. Therefore, the selection of the two-year NOI over NOIs with higher numerical values is also motivated by the need to take on board as many time series properties as possible. (ii) As a corollary to the preceding point, two-year NOIs are associated with greater degrees of freedom that are relevant for the modeling of conditional convergence. (iii) Consistent with Asongu (2013), the choice of higher numerical NOIs comes with the cost of low convergence rates and corresponding lengthier time spans to full convergence, which may not reflect the reality on the ground. For example, a policy recommendation with Absolute Convergence (AC) and Conditional Convergence (CC) of 47.9 years and 40.3 years respectively (based on the three-year NOI) for petroleum exporting countries (in the system GMM results) may not be welcomed by policy makers because it is a distant prospect and does not reflect the urgency of the capital flight issue under consideration. (iv) From an exploratory visual analysis, it is apparent that evidence of persistence in short-term or business-cycle disturbances is not associated with capital flight. Hence, the coefficient of autoregression is 2 (i.e., $\tau$ is set to 2 ) and the research computes the implied convergence rate by calculating $\sigma / 2$.

Accordingly, the estimated coefficient of the lagged difference outcome variable is divided by the number of NOIs (i.e., 2) because it has been employed to absorb shortterm disturbances. In essence, the criterion for assessing convergence is that the absolute value of the estimated lagged coefficient should be within the interval of zero and one $(0<|\sigma|<1)$. Hence, when the estimated lagged dependent variable falls within this interval in a specific fundamental characteristic, convergence can be established. The corresponding interpretation is that past variations induce a less proportionate influence on future variations, indicating that the difference in the left-hand side of Eq. (3) is decreasing over time given that the country is converging to a steady state (Asongu, 2013).

\section{Empirical analysis}

Presentation of results

This section looks at three principal concerns: (i) investigation of the presence of convergence; (ii) computation of the speed of convergence; and (iii) determination of the time needed for full (100\%) convergence. The summary of overall findings is presented in Table 1 in which the three concerns are addressed. Findings for absolute (unconditional) and conditional convergence are presented in Table 2 and Tables 3-4 respectively. 


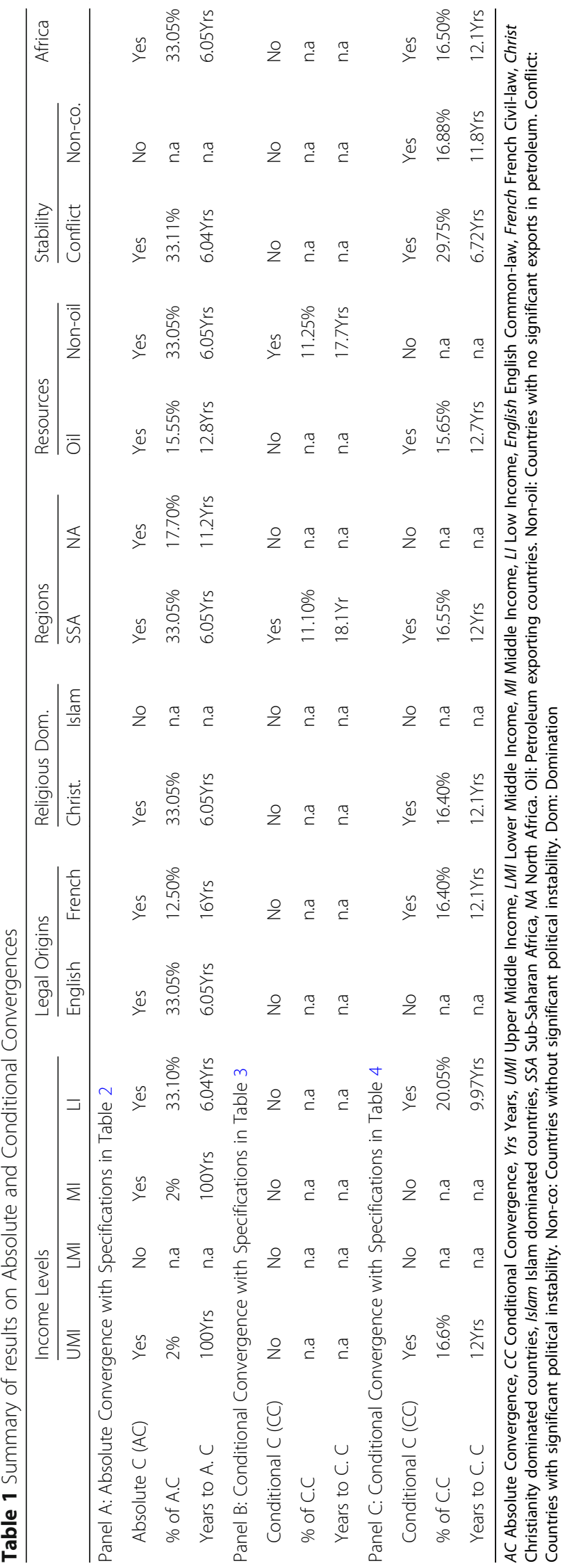




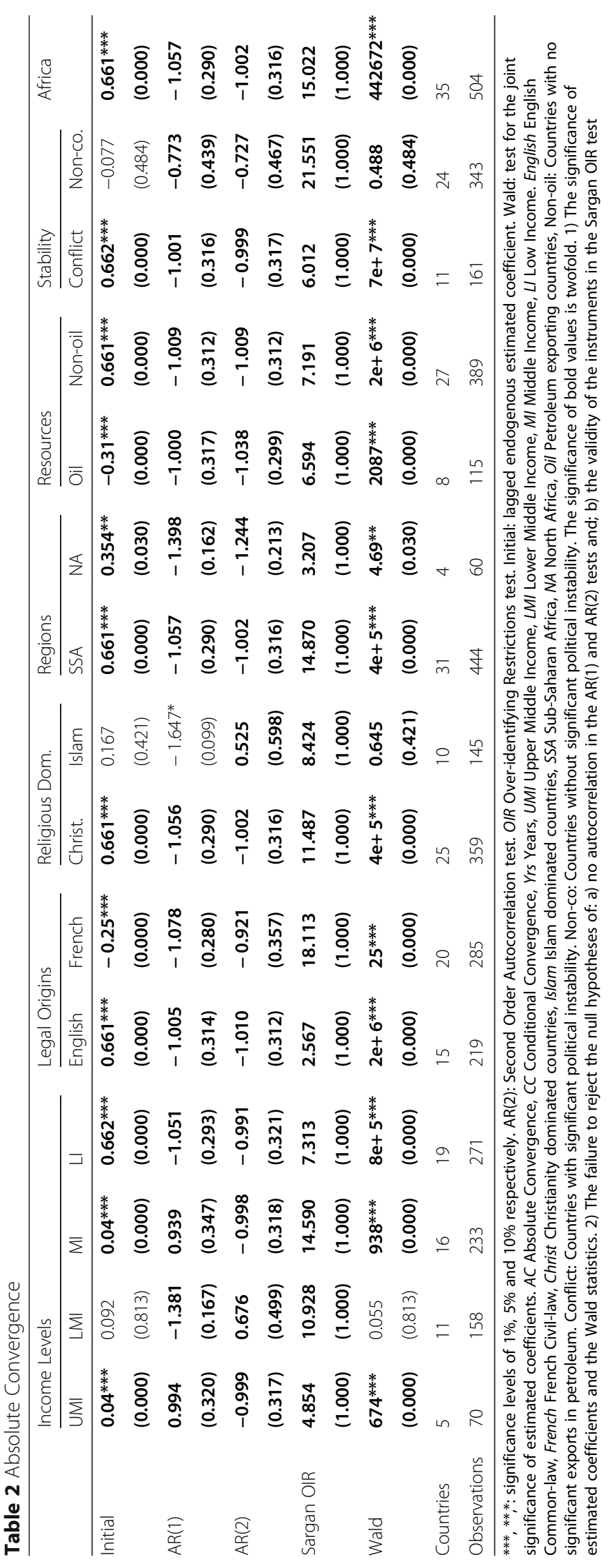




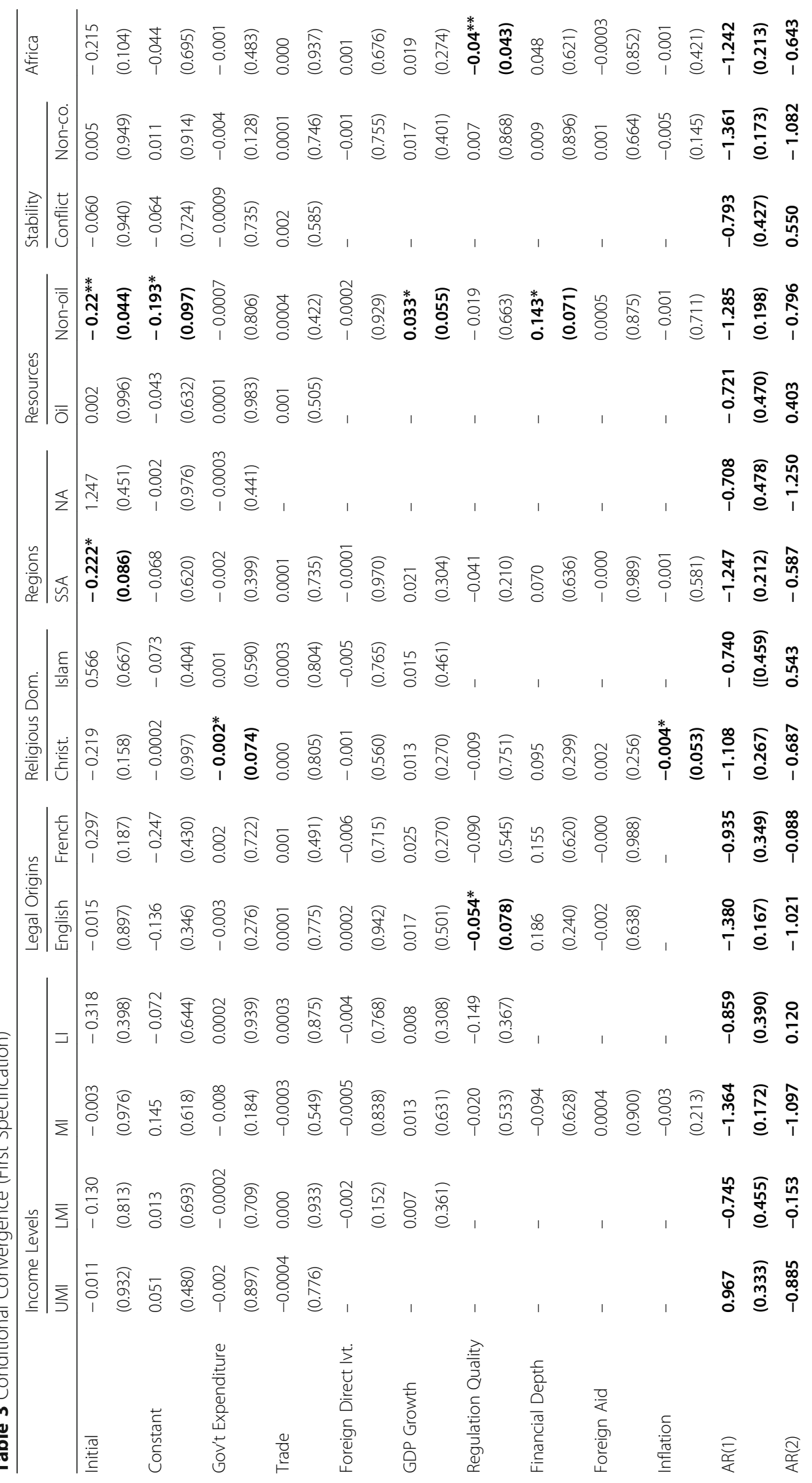




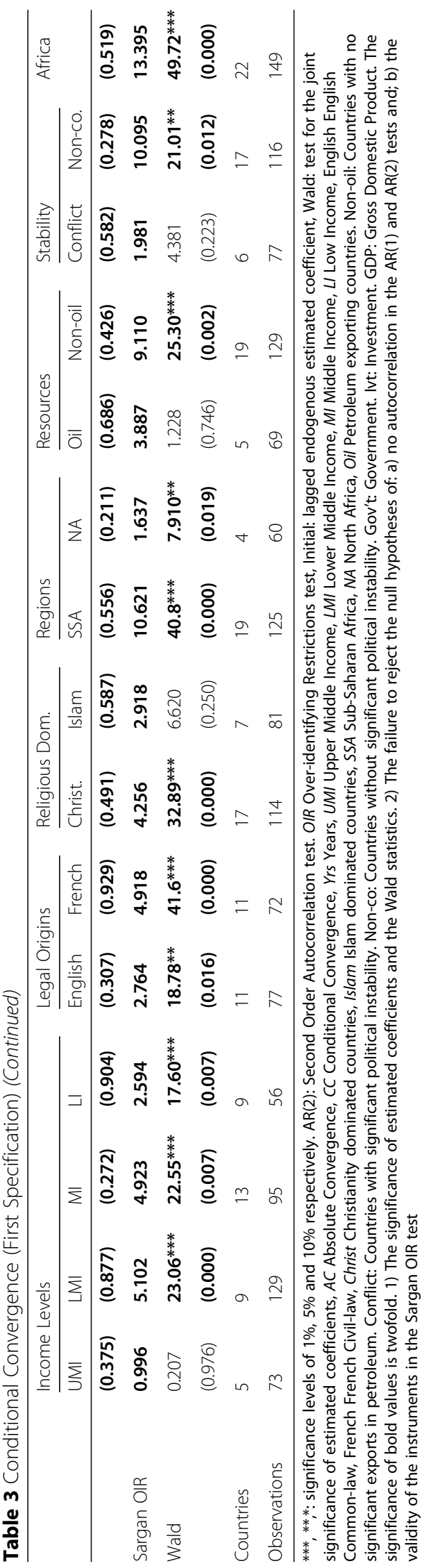




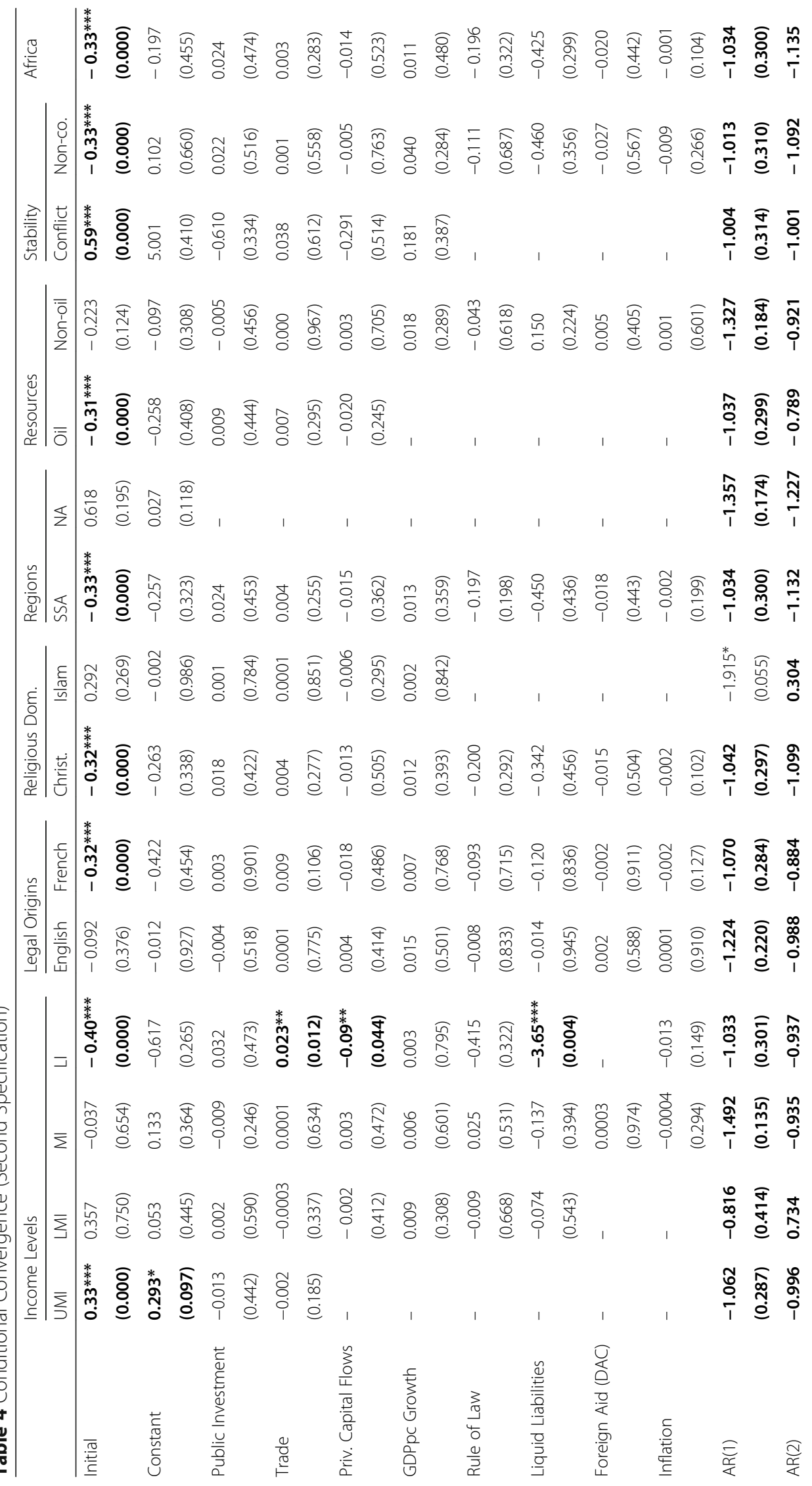




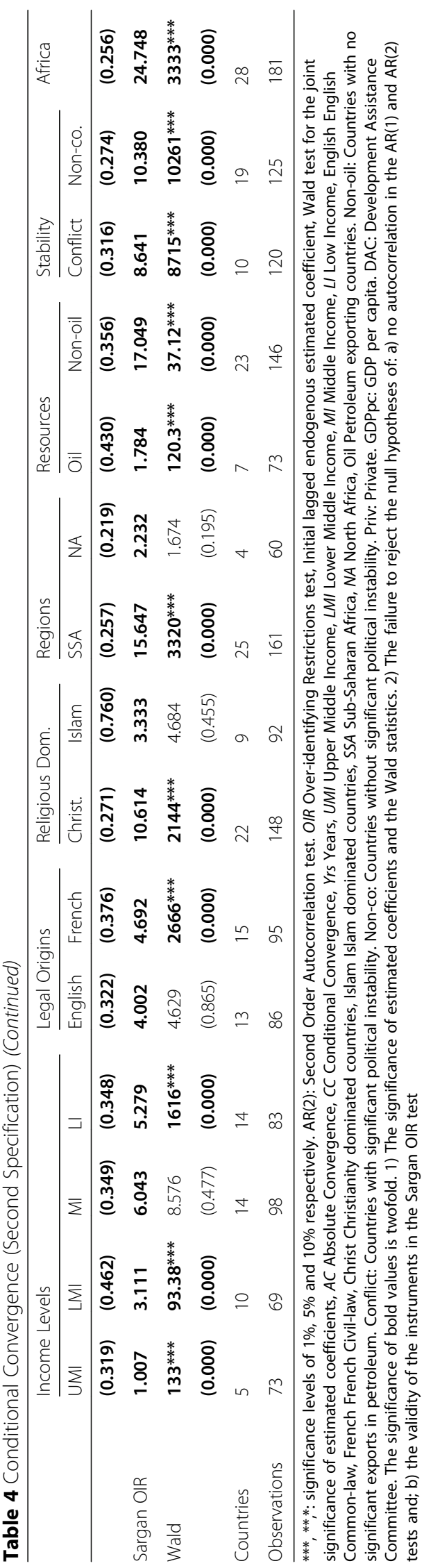


Absolute convergence is estimated with only the lagged difference of the endogenous variable as the independent variable, whereas conditional convergence is in the presence of the conditioning information set (control variables). Hence, unconditional convergence is estimated without $W_{i, t}$ : vector of determinants of capital flight (government expenditure, trade, FDI, GDP growth, regulation quality, financial depth, development assistance and inflation). ${ }^{2}$ Accordingly, in order to assess the validity of the model and indeed the convergence hypothesis, we perform two tests: (i) the Sargan test, which assesses over-identification restrictions, and (ii) the Arellano and Bond test for autocorrelation, which examines the null hypothesis of no autocorrelation. The Sargan test investigates whether the instruments are uncorrelated with the error term in the equation of interest. The null hypothesis is the stance that the instruments as a group are strictly exogenous and do not suffer from endogeneity, which is necessary for the validity of the GMM estimates. The $p$-values of estimated coefficients are disclosed in brackets in the line following the reported values of the estimated coefficients. We broadly observe that the null hypothesis of the Sargan test is not rejected in any of the regressions. Priority is given to the second order autocorrelation: AR (2) test in the first difference because it is more relevant than AR (1), as it detects autocorrelation in difference. For almost every model, we are unable to reject the AR (2) null hypothesis for the absence of autocorrelation, especially for conditional convergence specifications. Therefore, there is robust evidence that most of the models are free from autocorrelation at the $1 \%$ significance level.

Table 1 presents a summary of the findings from Tables 2-4. This entails results for $\mathrm{AC}, \mathrm{CC}$, the Speed of Absolute Convergence (SAC), the Speed of Conditional Convergence (SCC) and the rate required to achieve full (100\%) convergence in both types of convergences.

From a general perspective, the following conclusions could be drawn. (i) Conditional convergence findings based on the second specification (Table 4) are substantially more significant than those based on the first specification (Table 3). Therefore, conditional convergence is based on the variables we observe and empirically test (or model), which may not reflect all determinants of capital flight that facilitate the convergence process. Hence, the discussion of findings will be based only on the second specification for conditional convergence. (ii) Based on continental results, findings on "Petroleum exporting," "North African," "French civil law," "Middle-income" and "Upper-middleincome" countries significantly affect the absolute convergence process. In other words, these fundamental characteristics have rates of convergence that significantly differ from the $33.05 \%$ per annum observed for the African continent. Their respective degrees of convergence are much lower, implying a corresponding lengthier period required for full convergence. This disparity is most pronounced in "Middle-income" and "Upper-middle-income" countries, which both have a $2 \%$ per annum convergence rate and a time needed for full convergence of 100 years. (iii) Within the perspective of $\mathrm{CC}$, but for the results of "Conflict-affected" and "Low-income" countries, findings for African nations are broadly consistent across other fundamental characteristics. (iv)

${ }^{2}$ Note should be taken of the fact that the second vector of determinants entails the second set of control variables as presented in Table 4 (public investment, trade, private capital flows, GDP per capita growth, rule of law, liquid liabilities and development aid from DAC countries and inflation). 
Regardless of fundamental characteristic, from a projection date of 2010, a feasible timeframe for harmonizing policies is between 2016 and 2023.

\section{Discussion of results}

Before we discuss the results, it is important first and foremost to understand the economic intuition motivating absolute and conditional convergence of capital flight in the African continent. Absolute convergence in capital flight occurs when countries share the same fundamental characteristics with regard to factors governing capital flight, such that only cross-country variations in initial levels of capital flight exist. Absolute convergence thus results from factors such as, inter alia: significant exports of petroleum; political instability due to conflicts; the emphasis legal foundations placed on property rights, enforcement of rights and the fight against corruption; and the manner in which economic prosperity affects the propensity of additional wealth to be saved abroad. Absolute convergence also occurs because of adjustments common to fundamental characteristics (conflict-affected, high-income, or English common-law countries for example). Hence, based on the above intuition we could expect capital flight to be higher in petroleum-exporting and conflict-affected countries. This is a necessary but not a sufficient condition for speedy convergence because of disparities in initial conditions of capital flight. These differences in initial conditions depend on: (i) time-dynamic evidence of significant petroleum exports, either because of recent discovery or substantial decline in production; (ii) spontaneous reoccurrence of conflicts after relatively stable periods or arbitrary and unilateral violations of peace accords; and (iii) the diffusion of legal cultures transmitted by colonial powers over time through regionalization and globalization, such that there is no single, unifying system of law across the continent.

On the other hand, conditional convergence is that which is contingent on crosscountry disparities in structural and institutional characteristics that determine capital flight. In accordance with the economic growth literature (Barro \& Sala-i-Martin, 1992, 1995), conditional convergence depicts the kind of convergence whereby one's own long-term steady state (equilibrium) is contingent on the structural characteristics of its institutions in particular, and its economy in general. For example, non-petroleum exporting countries may differ significantly in the level of globalization, institutional quality, economic prosperity, financial development, price stability, and foreign aid, among other factors. To this end, our model for conditional convergence is contingent on institutional quality (rule of law and regulation quality), globalization (trade, FDI and private capital flows), financial development (at overall economic and financial system levels), economic prosperity (GDP growth at macro and micro levels) and inflation and development assistance (total NODA and NODA from DAC countries). ${ }^{3}$ Due to constraints in degrees of freedom, some models have not been conditional on all the determinants of capital flight outlined above. This is not a major issue because some conditional specifications in mainstream literature are limited to two macroeconomic control variables (Bruno et al., 2012).

We have observed the following from the findings. (i) Based on continental results, findings on "Petroleum exporting," "North Africa," "French civil law," "Middle-income" and

${ }^{3}$ FDI: Foreign Direct Investment. NODA: Net Official Development Assistance. DAC: Development Assistance Committee. 
"Upper-middle-income" countries significantly affect the absolute convergence process. The corresponding lower rate of convergence (higher time to full convergence) is the result of differences in initial conditions of capital flight. For instance, the difference in petroleum-exporting countries could be explained by significant variations in the initial conditions of capital flight discussed above, i.e., time-dynamic evidence of significant petroleum exports, either because of recent discovery or substantial decline in production. (ii) Within the perspective of CC, but for the results of 'Conflict-affected' and 'Low-income' countries, findings for African nations are broadly consistent across other fundamental characteristics. 'Conflict-affected' and 'Low-income' countries have a significantly higher rate of conditional convergence (lower time required for full conditional convergence) because of substantially lower cross-country differences in macroeconomic and institutional characteristics determining capital flight. Hence, cross-country differences in factors governing capital flight among "Conflict-affected" and "Low-income" countries are not very substantial. (iii) Regardless of fundamental characteristic, from a projection date of 2010, a feasible timeframe for harmonizing policies is between 2016 and 2023. This empirically indicates (both in absolute and conditional terms) that countries with lower rates of capital flight are catching-up their counterparts with higher rates. Consistent with the intuition motivating this analysis on policy harmonization, two inferences can be drawn: (i) convergence implies that adopting common policies against capital flight is feasible, and (ii) full (100\%) convergence within the specified time horizon reflects the implementation (or harmonization) of feasible policies without distinction of nationality or locality.

\section{Concluding implications and future directions}

An April 2015 World Bank report on the attainment of the Millennium Development Goal (MDG) extreme poverty target has revealed that extreme poverty has been decreasing in all regions of the world with the exception of sub-Saharan Africa (SSA), despite the sub-region enjoying more than two decades of growth resurgence. This study builds on a critique of Piketty's Capital in the twenty-first Century and recent methodological innovations on reverse Solow-Swan to review empirics on the adoption of common policy initiatives against a cause of extreme poverty in SSA: capital flight. The richness of the dataset enables the derivation of 14 fundamental characteristics of African capital flight based on income levels, legal foundations, natural resources, political stability, regional proximity, and religious domination. The main finding reveals that regardless of the fundamental characteristic, from a projection date of 2010, a feasible timeframe for harmonizing policies is between 2016 and 2023. In other words, the beginning of the post-2015 agenda on sustainable development goals coincides with the timeframe for common capital flight policies. Common capital flight policies will benefit sampled countries because capital flight is largely destined to wealthy countries and/or tax havens under the jurisdictions of wealthy countries. The implementation of common policies can be tailored within the auspices of the African Union because the African Union is currently spearheading the Continental Free Trade Area (CFTA) in Africa.

Consistent with Asongu (2014a), the following four points are relevant issues that need to be resolved to facilitate policy harmonization: (i) improvement of the investment climate and ease of doing business to deter capital fight based on prospects of higher returns; (ii) formulation of common policies that would culminate 
in the repatriation of corruption-related capital flight deposited in Western banks, and the improvement of formal institutions that will oversee the recovery of this stolen capital (as well as deter potentially corrupt officials); (iii) involvement of Western banks in particular and the international community in general; and (iv) challenging the legitimacy of a part of African debts. The purpose of this study has been to project more horizons for common policies against capital flight in Africa using more fundamental characteristics. More insights into policy measures against the underlying capital flight are available in Fofack and Ndikumana (2009) and Asongu (2014a).

Future studies devoted to extending extant literature may focus on more contemporary measures that are being tailored toward fighting illicit capital flight in the post-2015 sustainable development agenda.

\section{Appendix 1}

Table 5 Summary Statistics

\begin{tabular}{|c|c|c|c|c|c|c|}
\hline & Variables & Mean & S.D & Min. & Max. & Observations \\
\hline Capital Flight & & 3.647 & 28.643 & -13.637 & 399.14 & 540 \\
\hline \multirow[t]{2}{*}{ Expenditure } & Government Expenditure & 4.015 & 10.790 & -68.238 & 80.449 & 376 \\
\hline & Public Expenditure & 7.704 & 4.636 & 0.000 & 30.120 & 487 \\
\hline \multirow[t]{3}{*}{ Globalization } & Trade Openness & 69.503 & 38.157 & 8.199 & 246.89 & 557 \\
\hline & Foreign Direct Investment & 2.300 & 4.393 & -16.118 & 35.190 & 485 \\
\hline & Private Capital Flows & 2.410 & 4.555 & -16.118 & 35.295 & 489 \\
\hline \multirow[t]{2}{*}{ Institutional Quality } & Regulation Quality & -0.606 & 0.607 & -2.526 & 0.857 & 293 \\
\hline & Rule of Law & -0.697 & 0.648 & -2.312 & 0.863 & 294 \\
\hline \multirow[t]{2}{*}{ Economic Prosperity } & GDP growth & 3.539 & 4.624 & -29.178 & 24.176 & 559 \\
\hline & GDP per capita growth & 1.060 & 4.407 & -23.539 & 23.104 & 564 \\
\hline \multirow[t]{2}{*}{ Foreign Aid } & Total NODA & 10.223 & 9.915 & 0.054 & 62.344 & 559 \\
\hline & NODA from DAC countries & 6.062 & 6.144 & -0.175 & 53.017 & 559 \\
\hline \multirow[t]{3}{*}{ Finance and Inflation } & Money Supply & 0.305 & 0.202 & 0.001 & 1.224 & 472 \\
\hline & Liquid Liabilities & 0.235 & 0.186 & 0.001 & 1.017 & 474 \\
\hline & Inflation & 105.80 & 1226.3 & -100.00 & 24,411 & 520 \\
\hline \multirow[t]{14}{*}{ Categorization } & Upper Middle Income & 0.162 & 0.368 & 0.000 & 1.000 & 592 \\
\hline & Lower Middle Income & 0.297 & 0.457 & 0.000 & 1.000 & 592 \\
\hline & Middle Income & 0.459 & 0.498 & 0.000 & 1.000 & 592 \\
\hline & Low Income & 0.540 & 0.498 & 0.000 & 1.000 & 592 \\
\hline & English & 0.405 & 0.491 & 0.000 & 1.000 & 592 \\
\hline & French & 0.594 & 0.491 & 0.000 & 1.000 & 592 \\
\hline & Christianity & 0.702 & 0.457 & 0.000 & 1.000 & 592 \\
\hline & Islam & 0.297 & 0.457 & 0.000 & 1.000 & 592 \\
\hline & Sub-Saharan Africa & 0.891 & 0.310 & 0.000 & 1.000 & 592 \\
\hline & North Africa & 0.108 & 0.310 & 0.000 & 1.000 & 592 \\
\hline & Oil & 0.216 & 0.412 & 0.000 & 1.000 & 592 \\
\hline & Non-oil & 0.783 & 0.412 & 0.000 & 1.000 & 592 \\
\hline & Conflict & 0.297 & 0.457 & 0.000 & 1.000 & 592 \\
\hline & Non-conflict & 0.702 & 0.457 & 0.000 & 1.000 & 592 \\
\hline
\end{tabular}

SD Standard Deviation, Min Minimum, Max Maximum 


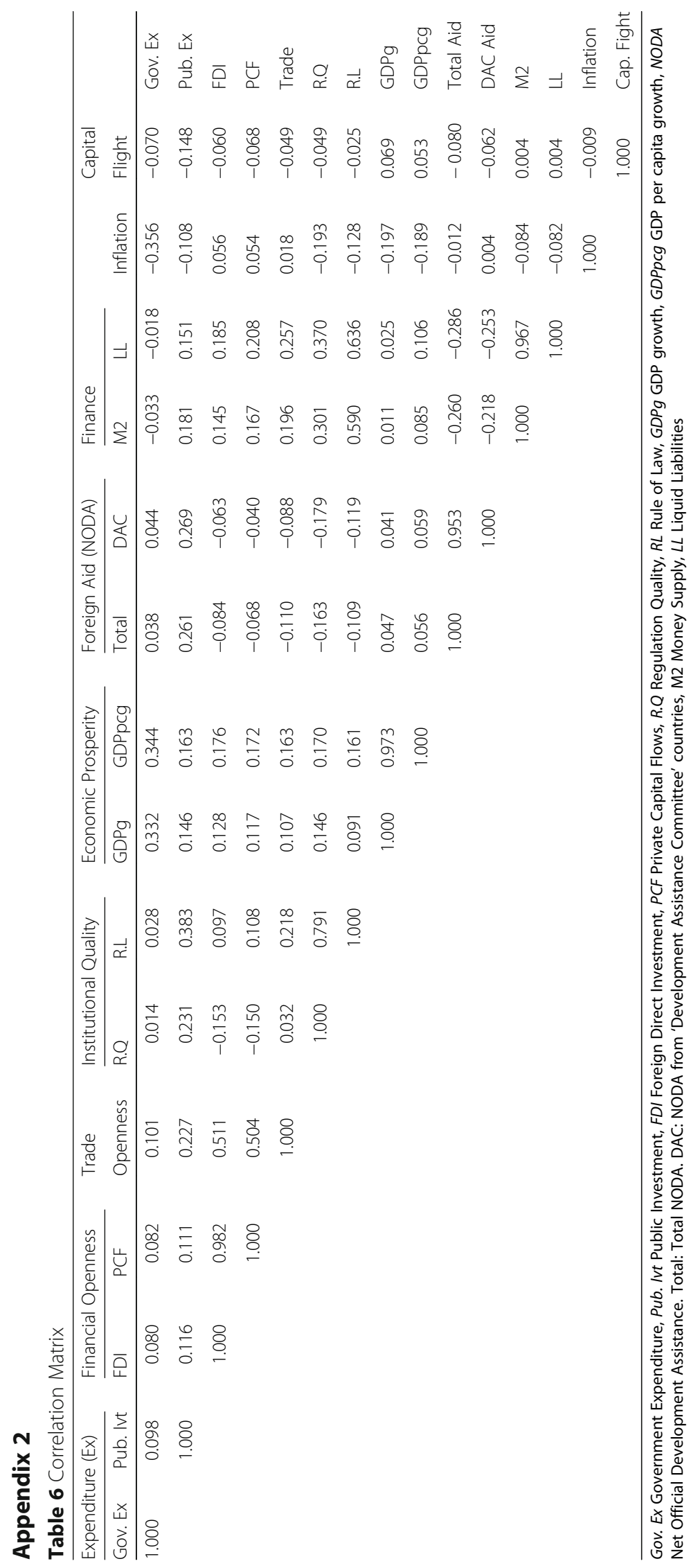




\section{Appendix 3}

Table 7 Definitions of variables

\begin{tabular}{|c|c|c|c|}
\hline Variables & Signs & Definitions of variables (Measurements) & Sources \\
\hline $\begin{array}{l}\text { Government } \\
\text { Expenditure }\end{array}$ & Gov. Ex & $\begin{array}{l}\text { Government Final Consumption } \\
\text { Expenditure (\% of GDP) }\end{array}$ & World Bank (WDI) \\
\hline Public Investment & Pub. Ivt & Gross Public Investment (\% of GDP) & World Bank (WDI) \\
\hline Foreign Investment & FDI & Foreign Direct Investment (\% of GDP) & World Bank (WDI) \\
\hline Private Capital Flows & PCF & Private Capital Flows (\% of GDP) & World Bank (WDI) \\
\hline Trade Openness & Trade & $\begin{array}{l}\text { Imports plus Exports of Goods and } \\
\text { Services (\% of GDP) }\end{array}$ & World Bank (WDI) \\
\hline Regulation Quality & R.Q & $\begin{array}{l}\text { Regulation Quality (estimate): Measured } \\
\text { as the ability of the government to } \\
\text { formulate and implement sound policies } \\
\text { and regulations that permit and promote } \\
\text { private sector development. }\end{array}$ & World Bank (WDI) \\
\hline Rule of Law & R.L & $\begin{array}{l}\text { Rule of Law (estimate): Captures perceptions } \\
\text { of the extent to which agents have } \\
\text { confidence in and abide by the rules of society } \\
\text { and in particular the quality of contract } \\
\text { enforcement, property rights, the police, the } \\
\text { courts, as well as the likelihood of crime and } \\
\text { violence. }\end{array}$ & World Bank (WDI) \\
\hline GDP Growth & GDPg & Average annual GDP growth rate & World Bank (WDI) \\
\hline $\begin{array}{l}\text { GDP per capita } \\
\text { Growth }\end{array}$ & GDPpcg & Average annual GDP per capita growth rate & World Bank (WDI) \\
\hline Foreign Aid (1) & Total Aid & $\begin{array}{l}\text { Total Net Official Development } \\
\text { Assistance (\% of GDP) }\end{array}$ & World Bank (WDI) \\
\hline Foreign Aid (2) & DAC Aid & NODA from DAC Countries (\% of GDP) & World Bank (WDI) \\
\hline Financial Depth & M2 & Money Supply (\% of GDP) & World Bank (FDSD) \\
\hline Liquid Liabilities & $\mathrm{LL}$ & Financial System Deposits (\% of GDP) & World Bank (FDSD) \\
\hline Inflation & Inflation & Consumer Price Index (Annual \%) & World Bank (WDI) \\
\hline Capital Flight & Cap. Flight & Capital Flight (constant of 2010 in \% of GDP) & $\begin{array}{l}\text { Boyce \& Ndikumana } \\
(2012)\end{array}$ \\
\hline
\end{tabular}

FDSD Financial Development and Structure Database, WDI World Bank Development Indicators, NODA Net Official Development Assistance, DAC Development Assistance Committee 


\section{Appendix 4}

Table $\mathbf{8}$ Presentation of Countries

\begin{tabular}{|c|c|c|c|}
\hline Categories & Panels & Countries & Num \\
\hline \multirow[t]{4}{*}{$\begin{array}{l}\text { Income } \\
\text { Levels }\end{array}$} & $\begin{array}{l}\text { Upper Middle } \\
\text { Income }\end{array}$ & $\begin{array}{l}\text { Botswana, Algeria, South Africa, Gabon, Sao Tomé \& Principe, } \\
\text { Seychelles. }\end{array}$ & 6 \\
\hline & $\begin{array}{l}\text { Lower Middle } \\
\text { Income }\end{array}$ & $\begin{array}{l}\text { Tunisia, Lesotho, Nigeria, Cameroon, Côte d'Ivoire, Swaziland, Sudan, } \\
\text { Egypt, Morocco, Angola, Cape Verde. }\end{array}$ & 11 \\
\hline & Middle Income & $\begin{array}{l}\text { Botswana, Algeria, South Africa, Gabon, Sao Tomé \& Principe, } \\
\text { Seychelles, Tunisia, Lesotho, Nigeria, Cameroon, Côte d'Ivoire, } \\
\text { Swaziland, Sudan, Egypt, Morocco, Angola, Cape Verde. }\end{array}$ & 17 \\
\hline & Low Income & $\begin{array}{l}\text { Burkina Faso, Uganda, Chad, Congo Republic, Mozambique, Burundi, } \\
\text { Malawi, Congo Democratic Republic, Ghana, Rwanda, Ethiopia, Kenya, } \\
\text { Madagascar, Central African Republic, Zambia, Guinea, Mauritania, } \\
\text { Sierra Leone, Tanzania, Zimbabwe. }\end{array}$ & 20 \\
\hline \multirow[t]{2}{*}{ Legal Origins } & $\begin{array}{l}\text { English } \\
\text { Common-law }\end{array}$ & $\begin{array}{l}\text { Botswana, Lesotho, Uganda, Nigeria, Malawi, Ghana, Swaziland, Sudan, } \\
\text { Kenya, Zambia, South Africa, Sierra Leone, Tanzania, Seychelles, } \\
\text { Zimbabwe. }\end{array}$ & 15 \\
\hline & French Civil-law & $\begin{array}{l}\text { Tunisia, Burkina Faso, Chad, Congo Republic, Mozambique, Burundi, } \\
\text { Cameroon, Congo Democratic Republic, Côte d'Ivoire, Algeria, Rwanda, } \\
\text { Ethiopia, Madagascar, Egypt, Central African Republic, Morocco, Guinea, } \\
\text { Mauritania, Gabon, Angola, Cape Verde, Sao Tomé \& Principe. }\end{array}$ & 22 \\
\hline \multirow[t]{2}{*}{$\begin{array}{l}\text { Religious } \\
\text { Domination }\end{array}$} & Christianity & $\begin{array}{l}\text { Botswana, Lesotho, Uganda, Congo Republic, Mozambique, Burundi, } \\
\text { Malawi, Cameroon, Congo Democratic Republic, Côte d'Ivoire, Ghana, } \\
\text { Swaziland, Rwanda, Ethiopia, Kenya, Madagascar, Central African } \\
\text { Republic, Zambia, South Africa, Gabon, Angola, Tanzania, Cape Verde, } \\
\text { Sao Tomé \& Principe, Seychelles, Zimbabwe. }\end{array}$ & 26 \\
\hline & Islam & $\begin{array}{l}\text { Tunisia, Burkina Faso, Nigeria, Chad, Sudan, Algeria, Egypt, Morocco, } \\
\text { Guinea, Mauritania, Sierra Leone. }\end{array}$ & 11 \\
\hline \multirow[t]{2}{*}{ Regions } & $\begin{array}{l}\text { Sub-Saharan } \\
\text { Africa }\end{array}$ & $\begin{array}{l}\text { Botswana, Lesotho, Uganda, Nigeria, Malawi, Ghana, Swaziland, Sudan, } \\
\text { Kenya, Zambia, South Africa, Sierra Leone, Tanzania, Seychelles, } \\
\text { Zimbabwe, Burkina Faso, Chad, Congo Republic, Mozambique, Burundi, } \\
\text { Cameroon, Congo Democratic Republic, Côte d'Ivoire, Rwanda, } \\
\text { Ethiopia, Madagascar, Central African Republic, Guinea, Mauritania, } \\
\text { Gabon, Angola, Cape Verde, Sao Tomé \& Principe. }\end{array}$ & 33 \\
\hline & North Africa & Algeria, Egypt, Morocco, Tunisia. & 4 \\
\hline \multirow[t]{2}{*}{ Resources } & $\begin{array}{l}\text { Petroleum } \\
\text { Exporting }\end{array}$ & $\begin{array}{l}\text { Nigeria, Chad, Congo Republic, Cameroon, Sudan, Algeria, Gabon, } \\
\text { Angola. }\end{array}$ & 8 \\
\hline & $\begin{array}{l}\text { Non-Petroleum } \\
\text { Exporting }\end{array}$ & $\begin{array}{l}\text { Botswana, Lesotho, Uganda, Malawi, Ghana, Swaziland, Kenya, Zambia, } \\
\text { South Africa, Sierra Leone, Tanzania, Seychelles, Zimbabwe, Burkina } \\
\text { Faso, Mozambique, Burundi, Congo Democratic Republic, Côte d'Ivoire, } \\
\text { Rwanda, Ethiopia, Madagascar, Central African Republic, Guinea, } \\
\text { Mauritania, Cape Verde, Sao Tomé \& Principe, Egypt, Morocco, Tunisia. }\end{array}$ & 29 \\
\hline \multirow[t]{2}{*}{ Stability } & Conflict & $\begin{array}{l}\text { Uganda, Mozambique, Burundi, Congo Democratic Republic, Sudan, } \\
\text { Rwanda, Ethiopia, South Africa, Angola, Sierra Leone, Zimbabwe. }\end{array}$ & 11 \\
\hline & Non-Conflict & $\begin{array}{l}\text { Botswana, Lesotho, Nigeria, Malawi, Ghana, Swaziland, Kenya, Zambia, } \\
\text { Tanzania, Seychelles, Burkina Faso, Chad, Congo Republic, Cameroon, } \\
\text { Côte d'Ivoire, Madagascar, Central African Republic, Guinea, Mauritania, } \\
\text { Gabon, Cape Verde, Sao Tomé \& Principe, Algeria, Egypt, Morocco, } \\
\text { Tunisia. }\end{array}$ & 26 \\
\hline
\end{tabular}

Num Number of cross sections (countries)

\section{Abbreviations}

AC: Absolute Convergence; ADI: African Development Indicators; CC: Conditional Convergence; DAC: Development Assistance Committee; FDI: Foreign Direct Investment; FDSD: Financial Development and Structure Database; GDP: Gross Domestic Product; GMM: Generalised Method of Moments; IPRs: Intellectual Property Rights; LRA: Lord Resistance Army; MDG: Millennium Development Goal; NODA: Net Official Development Assistance; NOI: Nonoverlapping intervals; OIR: Over-identifying restrictions; OLS: Ordinary Least Squares; SSA: Sub-Saharan Africa; WB: World Bank

Acknowledgements

The authors are indebted to the editor and reviewers for constructive comments. 


\section{Authors' contributions}

SAA participated in the writing of the manuscript and data analysis. JU participated in the revision of the manuscript. ENO participated in the revision of the manuscript. The author(s) read and approved the final manuscript.

\section{Authors' information}

Prof. Simplice A. Asongu holds a PhD from Oxford Brookes University and is currently the Lead Economist and Director of the African Governance and Development Institute (Yaoundé, Cameroon). He is also a: Senior Research Fellow at the Africa Growth Institute (Cape Town, South Africa); PhD Supervisor at Covenant University (Ota, Nigeria), the University of Ghana (Accra, Ghana) and Midlands State University (Gweru, Zimbabwe); DBA Supervisor at Management College of Southern Africa (Durban, South Africa) and Research Associate at the University of South Africa (Pretoria, South Africa), University of Buea (Buea, Cameroon) and Oxford Brookes University (Oxford, UK). He is also Associate Editor in some journals including the Journal of Economic Surveys, the Journal of African Business and the International Journal of Education Economics and Development

Dr. Joseph I. Uduji holds Ph. D (Marketing), Ph. D (Public Administration), M. Sc (Marketing), M. Sc (Public Relations), MBA (Business Administration) and MPA (Public Administration) from the University of Nigeria, Nsukka and Enugu Campuses. While he lectures business and development courses in the University of Nigeria, he is also a Visiting Professor to the Catholic University of Cameroon, Bamenda. His current research interests include impact assessment of multinationals corporate social responsibility in host communities of developing countries.

Mr. Elda N. Okolo-Obasi holds B. Sc (Agricultural Economics) and M. Sc (Development Studies) from the University of Nigeria, Nsukka and Enugu Campuses. He is a doctoral student and research fellow in the Institute for Development Studies, University of Nigeria. His current research interests include economic analysis of multinationals corporate social responsibility impact in host communities of developing countries.

\section{Funding}

This is an unfunded paper.

\section{Availability of data and materials}

The data for this paper is available upon request. This article does not contain any studies with human participants or animals performed by the authors.

\section{Competing interests}

The authors are self-funded and have received no funding for this manuscript. The authors also have no conflict of interest.

\section{Author details}

${ }^{1}$ Research Department, African Governance and Development Institute, P. O. Box 8413, Yaoundé, Cameroon. ${ }^{2}$ Department of Marketing, Faculty of Business Administration, Enugu Campus, University of Nigeria, Nsukka, Nigeria.

${ }^{3}$ Institute for Development Studies, Enugu Campus, University of Nigeria, Nsukka, Nigeria.

Received: 20 November 2018 Accepted: 11 February 2020

Published online: 17 February 2020

\section{References}

Arellano M, Bond S (1991) Some tests of specification for panel data: Monte Carlo evidence and an application to employment equations. Rev Econ Stud 58(2):277-297

Arellano M, Bover O (1995) Another look at the instrumental variable estimation of error-components models. J Econ 68(1):29-51 Asongu SA (2013) Harmonizing IPRs on software piracy: empirics of trajectories in Africa. J Bus Ethics 118(3):667-682 Asongu SA (2014a) Fighting African capital flight: empirics on benchmarking policy harmonization. Eur J Comp Econ 11(1):93-122 Asongu SA (2014b) African financial development dynamics: big time convergence. Afr J Econ Manag Stud 5(2):160-194 Asongu SA (2015) Determinants of health Professional's migration in Africa: a WHO based assessment. Eur J Health Econ 42(7):666-686 Asongu SA, Amankwah-Amoah J (2018) Mitigating capital flight through military expenditure: insight from 37 African countries. Res Int Bus Financ 45(October):38-53

Asongu SA, Kodila-Tedika O (2017) Is poverty in the African DNA (gene)? S Afr J Economics 85(4):533-552

Asongu SA, le Roux S (2017) Enhancing ICT for inclusive human development in sub-Saharan Africa. Technol Forecast Soc Chang 118(May):44-54

Asongu SA, le Roux S (2019) Understanding sub-Saharan Africa's extreme poverty tragedy. Int J Public Adm 42(6):457-467

Asongu SA, Nting RT, Osabuohien ES (2019) "One bad turn deserves another: how terrorism sustains the addiction to capital flight in Africa", journal of Industry. Competition and Trade 19(3):501-535

Asongu SA, Nwachukwu J (2016a) Rational asymmetric development, Piketty and poverty in Africa. Eur J Comp Econ 13(2):221-246 Asongu SA, Nwachukwu J (2016b) Revolution empirics: predicting the Arab spring. Empir Econ 51(2):439-482

Asongu SA, Nwachukwu J (2017) Fighting Capital Flight in Africa: Evidence from Bundling and Unbundling Governance. J Ind, Competition Trade 17(3):305-323

Barro RJ, Sala-i-Martin X (1992) Convergence. J Polit Econ 100(2):223-25

Barro RJ, Sala-i-Martin X (1995) Economic growth. The MIT Press, Cambridge, MA

Baumol WJ (1986) Productivity, growth, convergence and welfare: what the long run data show. Am Econ Rev 76(5):1072-1085 Blundell R, Bond S (1998) Initial conditions and moment restrictions in dynamic panel data models. J Econ 87(1):115-143 Bond S, Hoeffler A, Tample J (2001) GMM estimation of empirical growth models. University of Oxford, Oxford Boyce JK, Ndikumana L (2003) Public debt and private assets: explaining capital flight from sub-Saharan African countries. World Dev 31(1):107-130 
Boyce JK, Ndikumana L (2012a) Capital flight from sub-Saharan African countries: updated estimate, 1970-2010. University of Massachusetts, Political Economy Research Institute http://www.peri.umass.edu/fileadmin/pdf/ADP/SSAfrica_capitalflight_ Oct23_2012.pdf (accessed: 9/12/2013)

Boyce JK, Ndikumana L (2012b) Rich presidents of poor nations: capital flight from resource-rich countries in Africa. University of Massachusetts, Political Economy Research Institute http://concernedafricascholars.org/wp-content/uploads/2012/11/ caploss01-ndiku-14th.pdf (accessed: 9/12/2013)

Bruno G, De Bonis R, Silvestrini A (2012) Do financial systems converge? New evidence from financial assets in OECD countries. J Comp Econ 40(1):141-155

Chao X, Kou G, Peng Y, Alsaadi FE (2019) Behavior monitoring methods for trade-based money laundering integrating macro and micro Prudential regulation: a case from China. Technol Econ Dev Econ. https://doi.org/10.3846/tede.2019.9383

Efobi U, Asongu S, Okafor C, Tchamyou V, Tanankem B (2019) Remittances, finance and industrialisation in Africa. J Multinational Financial Management 49:54-66 (march, 2019)

Efobi U, Asongu SA (2016) Terrorism and capital flight from Africa. Int Econ 148:81-94

Efobi UR, Tanankem BV, Asongu SA (2018) Female economic participation with information and communication technology (ICT) advancement: evidence from sub Saharan Africa. S Afr J Econ 86(2):231-246

Fofack H, Ndikumana L (2009) Potential gains from capital flight repatriation from sub-Saharan African countries, World Bank Working Paper no. 5024, Washington

Fung MK (2009) Financial development and economic growth: convergence or divergence? J Int Money Financ 28(1):56-67

Gankou J-M, Bendoma M, Sow MN (2016) The institutional environment and the link between capital flows and capital flight in Cameroon. Afr Dev Rev 28(S1):65-87

Islam N (1995) Growth empirics: a panel data approach. Q J Econ 110(4):1127-1170

Kelsey D, le Roux S (2017) Dragon slaying with ambiguity: theory and experiments. J Public Econ Theory 19(1):178-197

Kelsey D, le Roux S (2018) Strategic ambiguity and decision-making: an experimental study. Theory Decis 18(3):387-404

Kou G, Chao X, Peng Y, Alsaadi FE (2019) Machine learning methods combined with financial systemic risk. Technol Econ Dev Econ. https://doi.org/10.3846/tede.2019.8740

Kou G, Ergu D, Chen Y, Lin C (2016) Pairwise comparison matrix in multiple criteria decision making. Technol Econ Dev Econ 22(5):738-765

Kou G, Lu Y, Peng Y, Shi Y (2012) Evaluation of classification algorithms using MCDM and rank correlation. Int J Info Technol Decis Making 11(1):197-225

Kou G, Peng Y, Wang G (2014) Evaluation of clustering algorithms for financial risk analysis using MCDM methods. Inf Sci 275(August):1-12

Kou G, Yang P, Xiao F, Chen Y, Alsaadi FE (2019) Evaluation of feature selection methods for text classification with small datasets using multiple criteria decision-making methods. Appl Soft Comput. https://doi.org/10.1016/j.asoc.2019.105836

Kwaramba M, Mahonye N, Mandishara L (2016) Capital flight and trade Misinvoicing in Zimbabwe. Afr Dev Rev 28(S1):50-64 La Porta R, Lopez-de-Silanes F, Shleifer A, Vishny RW (1998) Law and finance. J Polit Econ 106:1113-1155

Li G, Kou G, Peng Y (2016) A group decision making model for integrating heterogeneous information. IEEE Trans Syst Man Cybern: Syst. https://doi.org/10.1109/tsmc.2016.2627050

Li T, Kou G, Peng Y, Shi Y (2014) "Classifying with adaptive hyper-spheres: an incremental classifier based on competitive learning", IEEE transactions on systems, man, and cybernetics: systems, pp 1-12. https://doi.org/10.1109/TSMC.2017.2761360

Mankiw NG, Romer D, Weil DN (1992) A contribution to the empirics of economic growth. Q J Econ 107(2):407-437 Moulemvo A (2016) Impact of capital flight on public social expenditure in Congo-Brazzaville. Afr Dev Rev 28(S1):113-123

Mpenya AHT, Metseyem C, Epo BN (2016) Natural resources and capital flight in Cameroon. Afr Dev Rev 28(S1):88-99

Muchai DN, Muchai J (2016) Fiscal policy and capital flight in Kenya. Afr Dev Rev 28(S1):8-21

Narayan PK, Mishra S, Narayan S (2011) Do market capitalization and stocks traded converge? New global evidence. J Bank Financ 35(10):2771-2781

Ndiaye AS, Siri A (2016) Capital flight from Burkina Faso: drivers and impact on tax revenue. Afr Dev Rev 28(S1):100-112

Ndikumana L (2016) Causes and effects of capital flight from Africa: lessons from case studies. Afr Dev Rev 28(S1):2-7

Piketty T (2014) Capital in the Twenty First Century. Harvard University Press, Cambridge.

Ramiandrisoa OT, Rakotomanana JM (2016) Why is there capital flight from developing countries? The case of Madagascar. Afr Dev Rev 28(S1):22-38

Tchamyou VS (2019a) Education, lifelong learning, inequality and financial access: evidence from African countries. Contemp Soc Sci. https://doi.org/10.1080/21582041.2018.1433314

Tchamyou VS (2019b) The role of information sharing in modulating the effect of financial access on inequality. J Afr Bus 20(3):317-338

Tchamyou VS, Asongu SA (2017) Information sharing and financial sector development in Africa. J Afr Bus 18(7):24-49

Tchamyou VS, Asongu SA, Nwachukwu JC (2018) Effects of asymmetric information on market timing in the mutual fund industry. Int J Manag Financ 14(5):542-557

Tchamyou VS, Erreygers G, Cassimon D (2019) Inequality, ICT and financial access in Africa. Technol Forecasting Soc Change 139:169-184

Weeks J (2012) Macroeconomic impact of capital flows in sub-Saharan African countries, 1980-2008, Association of Concerned Africa Scholar Bulletin, vol 87, pp 1-7

Word Bank (2015). "World Development Indicators', World Bank Publications http://www.gopa.de/fr/news/world-bank-releaseworld-development-indicators-2015 (Accessed: 26/11/2015)

Zhang H, Kou G, Peng Y (2019) Soft consensus cost models for group decision making and economic interpretations. Eur J Oper Res 277(3):964-980

\section{Publisher's Note}

Springer Nature remains neutral with regard to jurisdictional claims in published maps and institutional affiliations. 